\title{
PELATIHAN PENYUSUNAN LAPORAN KEUANGAN DENGAN MENGGUNAKAN MS EXCEL BAGI KOPERASI JASA KEUANGAN SYARIAH DI KOTA PADANG
}

\author{
Muthia Roza Linda ${ }^{*}$ \\ Sutiyem ${ }^{2}$ \\ Dessy Trismiyanti ${ }^{3}$ \\ Trimardi Jaya Putra 4 \\ Jasmalinda ${ }^{5}$
}

${ }^{1 *} J u r u s a n$ Manajemen, Fakultas Ekonomi Universitas Negeri Padang, Padang, Indonesia 2,3,4,5 Sekolah Tinggi Ilmu Ekonomi Perdagangan, Padang, Indonesia

Kata Kunci: [Koperasi,

Laporan Keuangan,

Ceramah, Komputer]

muthia@fe.unp.ac.id ${ }^{*}$

sutiyem.yem@gmail.com ${ }^{2)}$

dessytrismiyanti123@gmail.com ${ }^{3)}$

tjputra1@gmail.com ${ }^{4}$

jasmalinda819@gmail.com ${ }^{5)}$

\begin{abstract}
Abstrak: Latar belakang program pengabdian adalah Kurangnya pemahaman dan pengetahuan pengurus koperasi tentang pentingnya laporan keuangan yang tersedia tepat pada waktunya, belum dimilikinya sistem administrasi keuangan dan manajemen keuangan yang baik pada koperasi, dan tersedianya laporan keuangan yang bisa menjadi pertimbangan bagi masyarakat dalam menilai kinerja koperasi. Metode pengabdian masyarakat ini adalah (1) ceramah bervariasi dan (2) praktek komputer. Hasilnya; Memberikan informasi kepada anggota manfaat yang diperoleh setelah menjadi anggota koperasi, Prestasi keuangan koperasi selama suatu periode, Informasi mengenai kondisi keuangan koperasi, dan Sebagai bahan pertimbangan untuk menentukan jumlah sumberdaya dan jasa yang akan diberikan kepada koperasi.
\end{abstract}

Published by:

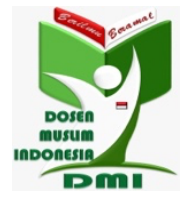

Copyright (C) 2021 The Author(s)

This article is licensed under CC BY 4.0 License

(cc) BY

ntcps:/ / amı-journais.org/ Jaı 


\section{Pendahuluan}

Koperasi adalah badan usaha yang beranggotakan orang atau badan hukum yang berlandaskan pada asas kekeluargaan dan demokrasi ekonomi. Kegiatan usaha koperasi merupakan penjabaran dari UUD 1945 pasal 33 ayat (1). Dengan adanya penjelasan UUD 1945 Pasal 33 ayat (1) koperasi berkedudukan sebagai soko guru perekonomian nasional dan sebagai bagian yang tidak terpisahkan dalam sistem perekonomian nasional.Sebagai salah satu pelaku ekonomi, koperasi merupakan organisasi ekonomi yang berusaha menggerakkan potensi sumber daya ekonomi demi memajukan kesejahteraan anggota. Karena sumber daya ekonomi tersebut terbatas, dan dalam mengembangkan koperasi harus mengutamakan kepentingan anggota, maka koperasi harus mampu bekerja seefisien mungkin dan mengikuti prinsip-prinsip koperasi dan kaidah-kaidah ekonomi.

Menurut Undang-undang No. 25 tahun 1992 Pasal 4 dijelaskan bahwa koperasi memiliki fungsi dan peranan antara lain yaitu mengembangkan potensi dan kemampuan ekonomi anggota dan masyarakat, berupaya mempertinggi kualitas kehidupan manusia, memperkokoh perekonomian rakyat, mengembangkan perekonomian nasional, serta mengembangkan kreativitas dan jiwa berorganisasi bagi pelajar bangsa.

Koperasi dapat disebut sebagai gambaran pondasi dasar ekonomi bangsa Indonesia karena mempunyai dasar azas kekeluargaan, akan tetapi kondisi saat ini tidak mudah menjalankan kegiatan perkoperasian. Permasalahan yang dihadapi koperasi beragam pada era globalisasi ini, seperti Koperasi jarang peminatnya, Sulitnya koperasi berkembang, Masalah permodalan, dan Masalah Internal dengan contoh sistem kerja, Re-generasi organisasi, sistem pengawasan kerja koperasi dan lain-lain. Oleh karena permasalahan koperasi sangat luas dan sangat komplek, maka diperlukan sebuah ide/pemecahan masalah yang dapat membantu koperasi untuk berkembang, dan apabila tidak segera diatasi maka akan sulit bagi kita untuk menyelesaikan masalah tersebut pada masa mendatang disebabkan masalah yang ada akan menjadi berlarutlarut dan dapat berdampak negatif bagi koperasi tersebut.

Permasalahan utama yang dihadapi Koperasi adalah kurangnya minat masyarakat untuk bergabung menjadi anggota koperasi sehingga menimbulkan munculnya masalah permodalan bagi koperasi karena modal koperasi berasal dari simpanan anggota. Jika anggota koperasi sedikit, maka modal koperasi yang tersedia juga sedikit yang akan mengakibatkan koperasi sulit untuk berkembang. Rendahnya minat masyarakat untuk menjadi anggota koperasi dikarenakan kurang kepercayaan anggota terhadap kepengurusan koperasi yang berdampak pada proses kegiatan simpan-pinjam para anggota, padahal itu adalah sumber dana pokok bagi perkoperasian untuk mengembangkan usaha-usahanya untuk mencari tambahan keuntungan atau hasil usaha. Hal lain yang menyebabkan kurangnya minat masyarakat untuk menjadi anggota dengan menyimpankan dana mereka melalui koperasi dikarenakan koperasi kalah bersaing dengan lembaga-lembaga yang bergerak dibidang pemberian modal, lembaga pemberian kredit atau lembaga penyimapanan dana contohnya perbankan.

Untuk mengatasi permasalahan yang dihadapi koperasi, terutama untuk menarik minat masyarakat agar mau bergabung sebagai anggota koperasi, maka koperasi harus memperbaiki system kerjanya dan menunjukkan kinerja yang baik kepada masyarakat. Kinerja yang dicapai koperasi dapat dilihat dari kemampuan koperasi tersebut dalam 
menghasilkan laba yang tercermin dalam laporan keuangan koperasi yang dilaporkan pada rapat anggota tahunan (RAT). Akan tetapi, banyak koperasi yang sering terlambat dalam melakukan RAT atau bahkan tidak melakukan RAT selama bertahun-tahun. Ini juga menjadi salah satu penyebab rendahnya kepercayaan masyarakat untuk menyerahkan modal mereka untuk dikelola oleh koperasi.

Berdasarkan sumber dari Dinas Koperasi dan UKM Kota Padang, jumlah koperasi yang terdapat di Kota Padang berjumlah 655, dari jumlah tersebut baru 220 koperasiyang telah melakukan RAT untuk tahun buku 2014 dan kurang lebih 30\% koperasi yang melakukan RAT secara tertib setiap tahunnya pada waktunya. Seperti yang terjadi pada kelompok koperasi jasa keuangan syariah (KJKS), dari $104 \mathrm{KJKS}$, baru 65 KJKS yang melaksanakan RAT untuk tahun buku 2014. Koperasi-koperasi yang tidak melakukan RAT atau sering terlambat dalam melakukan RAT dikarenakan mereka selalu terkendala dalam membuat laporan keuangan, karena banyak dari koperasi tersebut masih membuat laporan keuangan mereka secara manual karena mereka terkendala dalam hal modal jika harus membeli software keuangan yang akan memerlukan biaya tinggi untuk membuat laporan keuangan.

Untuk itu, perlu dilakukan pelatihan bagi pengurus koperasi tentang bagaimana cara membuat laporan keuangan yang praktis dan menggunakan aplikasi ms. Excel untuk mempermudahkan membuat laporan keuangan karena dengan menggunakan aplikasi ms. Excel laporan keuangan dalam bentuk neraca dan laporan laba rugi bisa langsung dihasilkan hanya dengan melakukan posting buku besar.

Tersedianya Laporan keuangan yang tepat pada waktunya, akan sangat bermanfaat bagi koperasi, karena dengan tersedia laporan keuangan, koperasi dapat melaksanakan RAT pada waktunya, sehingga anggota memperoleh gambaran bagaimana kondisi dari koperasi tersebut, serta laporan keuangan tersebut akan membantu koperasi untuk mendapatkan investor yang bersedia menanamkan modalnya ke koperasi dengan menjadi anggota koperasi.

Tujuan yang ingin dicapai dari kegiatan pengabdian pada masyarakat ini adalah:

1. Membekali pengurus koperasi di kota Padang agar memiliki pemahaman dan pengetahuan tentang pentingnya laporan keuangan untuk koperasi secara tepat.

2. Membekali pengurus koperasi tentang adminstrasi keuangan yang baik dalam pengelolaan keuangan koperasi.

3. Membekali pengurus koperasi dalam menyusun laporan keuangan secara praktis dengan menggunakan aplikasi ms. Excel..

\section{Metode Pelaksanaan}

Kegiatan pengabdian ini dilaksanakan di ruang kelas Fakultas Ekonomi Universitas Negeri Padang dengan jumlah peserta sebanyak 26 orang. Rencana awal kegiatan akan diadakan selama 2 hari, yaitu tanggal 24-25 Oktober 2015. Akan tetapi, dengan berbagai pertimbangan, kegiatan dilakukan selama satu hari namun full time, yaitu tanggal 24 Oktober 2015, dimulai dari jam 8 pagi hingga jam 17.30 kemudian dilanjutkan dengan latihan pembuatan laporan keuangan dengan aplikasi ms excel sesuai dengan materi pelatihan di koperasi masing-masing yang nantinya dikirimkan hasilnya kepanitia pengabdian via email. 
Kegiatan pengabdian dibagi atas dua sesi, sesi pertama dimulai dari jam 8.30 pagi hingga jam 12.30 siang dengan materi tentang laporan keuangan koperasi dan penganggaran keuangan koperasi, serta materi tentang PSAK untuk laporan keuangan koperasi kemudian dilanjutkan dengan diskusi tanya jawab dengan para pemateri. Sesi kedua dimulai jam 13.30 siang hingga jam 17.30 sore dengan materi tentang pengenalan aplikasi ms excel dan bagaimana pemanfaatan aplikasi ms excel untuk pembuatan laporan keuangan koperasi.

Pada awal kegiatan dilaksanakan, peserta pelatihan diberikan penjelasan mengenai pentingnya pengelolaan laporan keuangan koperasi dan pembuatan anggaran keuangan koperasi. Setelah pemberian materi, dilanjutkan dengan tanya jawab, agar peserta dapat lebih memahami arti pentingnya pengelolaan keuangan. Dan dengan tanya jawab, hal-hal yang meragukan dan tidak dipahami oleh peserta dapat mereka tanyakan langsung kepada pemateri. Melalui materi pada sesi pertama ini, diharapkan peserta dapat bertambah wawasan dan pengetahuannya dalam pengelolaan keuangan koperasi, dan mereka mampu untuk menerapkannya dalam kegiatan sehri-hari. Pada sesi pertama ini, pemateri didampingi oleh para instruktur untuk membimbing peserta dalam membuat anggaran keuangan koperasi yang sederhana.

Selanjutnya sesi kedua, peserta diberi materi tentang PSAK. Pada sesi kedua ini, dijelaskan apa yang dimaksud dengan PSAK dan apa kegunaan dari PSAK, sehingga para peserta dapat menerapkannya dalam aktivitas keuangannya. Selain itu, dari materi ini diharapkan peserta dapat mengetahui bagaimana cara penamaan dan penomoran suatu akun dari transaksi yang dilakukan.

Pada sesi terakhir, peserta diberikan materi tentang bagaimana membuat laporan keuangan dengan menerapkan aplikasi excel sehingga laporan akhir keuangan dapat selesai secara cepat dan menghitung berapa bunga serta pokok pinjaman anggota dengan menggunakan ms. excel.

Untuk mengukur hasil dari pelatihan ini, setiap peserta yang dibagi atas 6 kelompok, diminta untuk membuat laporan keuangan salah satu dari koperasi anggota untuk satu bulan berjalan dengan menggunakan aplikasi ms. excel yang telah mereka pelajari yang kemudian dikirimkan kepada panitia melalui email. Berdasarkan laporan yang dikirimkan oleh peserta, ternyata mereka dapat menerapkan palikasi ms. Excel ini dalam membuat laporan keuangan dan mereka menyatakan bahwa pekerjaan mereka dalam menyiapkan laporan bulanan koperasi sangat terbantu.

\section{Hasil dan Pembahasan}

Peserta pelatihan yang dilibatkan dalam kegiata pengabdian ini adalah para pelaksana pembukuan dan keuangan Koeprasi Jasa Keuangan Syariah di Kota Padang. Peserta dari kegiatan pengabdian ini berjumlah 26 orang. Mereka datang melalui undangan secara resmi melalui Dinas Koperasi dan UMKM Kota Padang. Dalam menentukan koperasi mana saja yang akan mengikuti pelatihan ini, panitia berkoordinasi dengan Dinas Koeprasi dan UMKM Kota Padang dengan menyebutkan bahwa koperasi yang mengikutinya adalah koperasi yang belum menggunakan suatu software khusus dalam pelaporan keuangannya. 


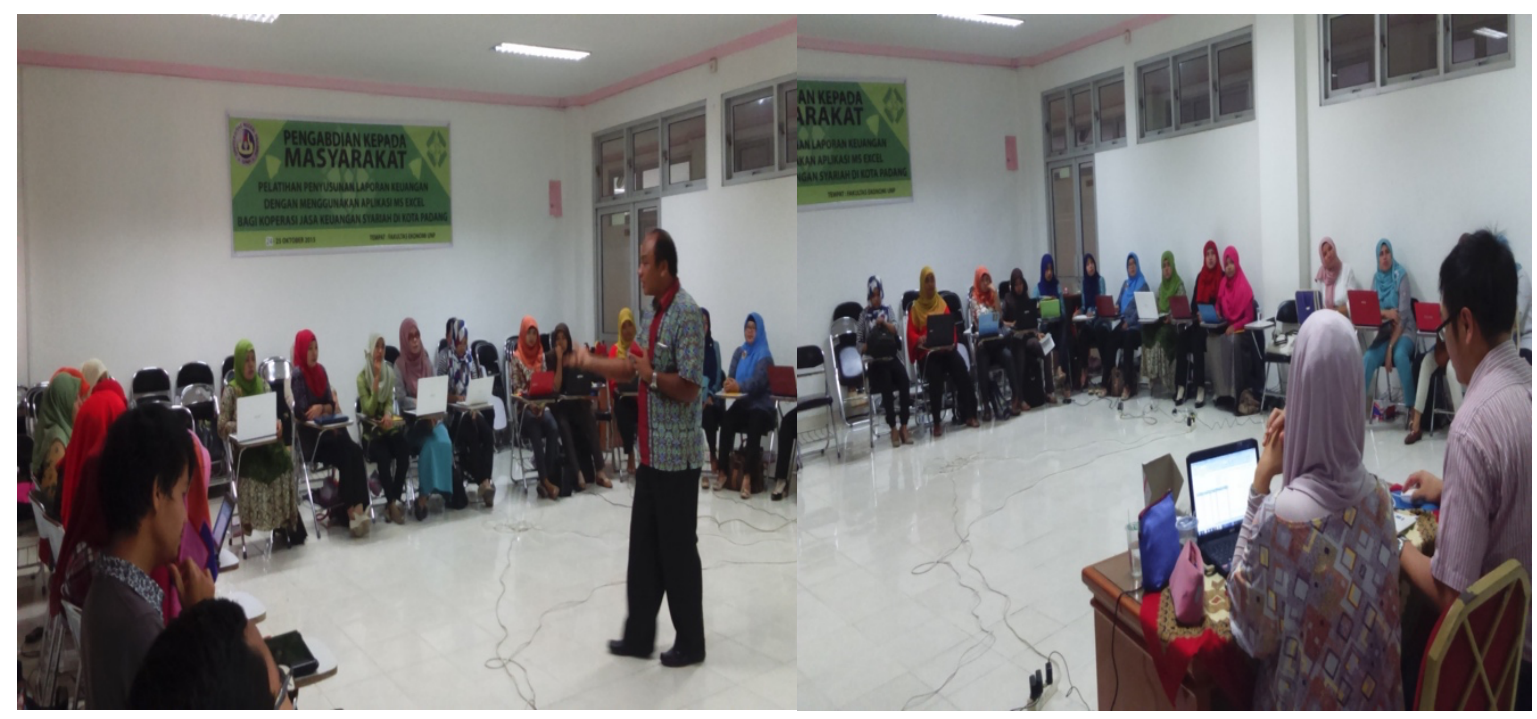

Gambar 1. Forum Kegiatan Pelatihan

Koperasi yang ditunjuk untuk mengikuti pelatihan ini sangat bersemangat saat diundang untuk mengikuti pelatihan, hal ini dapat dilihat dari respon yang cukup antusias yang ditunjukkan oleh para utusan koperasi tersebut yang datang tepat waktu pada jadwal yang ditetapkan, dan jumlah utusan yang hadir melebihi dari undangan yang disebarkan, karena ternyata para koordinator lapangan koperasi jasa keuangan ini juga hadir pada saat pelatihan dengan harapan mereka dapat menyebarkan pengertahuan ini kepada koperasi lainnya yang tidak mengikuti pelatihan ini.

Dalam pelaksanaan kegiatan pelatihan ini, para pelaksana pembukuan dan keuangan diberikan konsep dan wawasan mengenai bagaimana cara pengelolaan keuangan koperasi yang baik, dimulai dari bagaimana membuat anggaran keuangan koperasi, cara penyusunan dokumentasi keuangan dan penomorannya serta bagaimana penyusunan laporan keuangan dengan menggunakan aplikasi ms excel. Selama pelatihan, setiap selesai materi, para peserta diberikan pendampingan dalam penyusunan pengelolaan keuangan. Tindak lanjut dari kegiatan ini adalah para pengelola keuangan koperasi dapat mempraktekkan dalam kegiatannya sehari-hari tentang bagaimana cara menyusun dan membuat laporan keuangan koperasi sehingga pelaporan keuangan koperasi melalui Rapat Anggota Tahunan (RAT) dapat dilaksanakan tepat waktu.

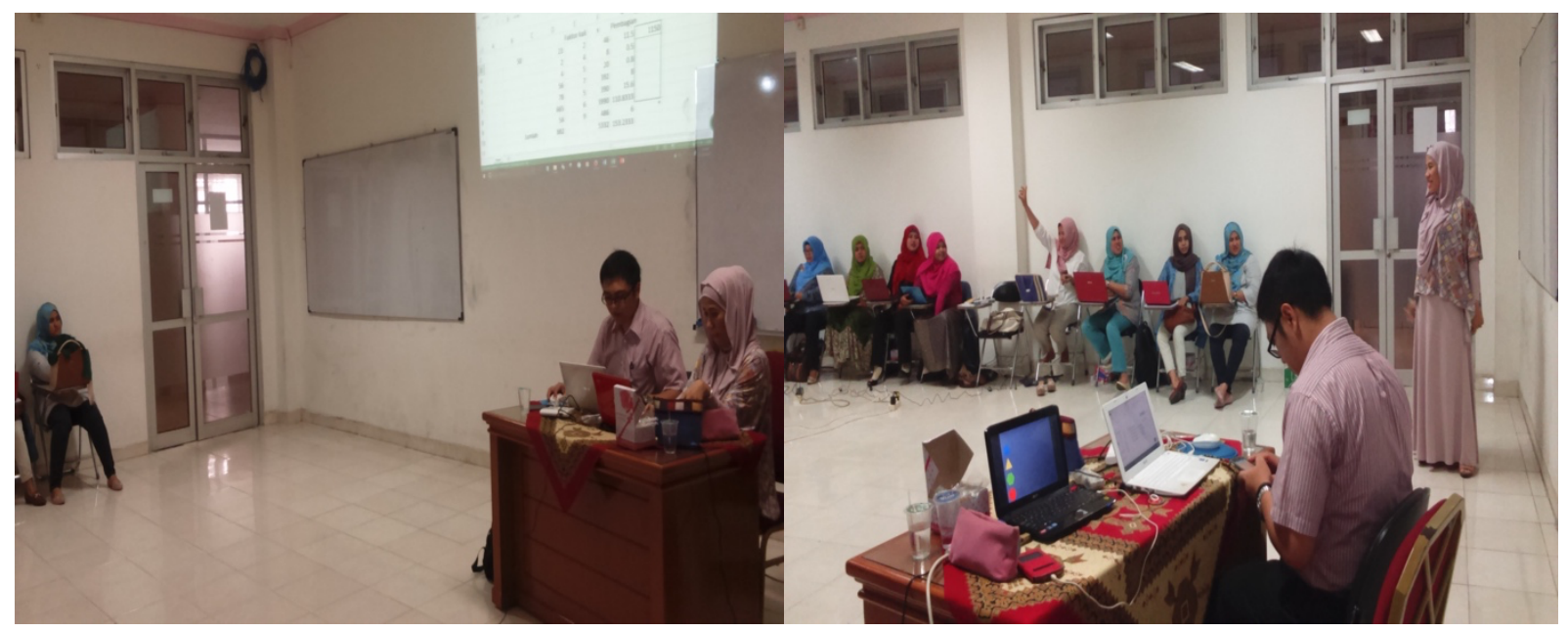

Gambar 2. Forum Kegiatan Pelatihan 
Melalui pelatihan penyusunan laporan keuangan dengan menggunakan aplikasi Ms. Excel bagi koperasi jasa keuangan syariah di kota Padang, maka diperoleh hasil sebagai berikut:

Tabel 1. Hasil Kegiatan Pelatihan Penyusunan Laporan Keuangan dengan Menggunakan Aplikasi Ms. Excel

\begin{tabular}{|c|c|c|c|}
\hline No & Kegiatan & Respon & Keterangan \\
\hline 1. & $\begin{array}{l}\text { Keuangan Koperasi } \\
\text { dan Penyusunan } \\
\text { Anggaran Koperasi }\end{array}$ & Sangat Bagus & $\begin{array}{l}\text { Peserta memahami } \\
\text { penyusunan anggaran kentingnya } \\
\text { koperasi sebagai pedoman dalam } \\
\text { operasional koperasi }\end{array}$ \\
\hline 2. & $\begin{array}{l}\text { PSAK dalam } \\
\text { keuangan koperasi }\end{array}$ & Sangat Bagus & $\begin{array}{lll}\text { Peserta memahami cara penamaan } \\
\text { suatu Transaksi dalam laporan }\end{array}$ \\
\hline 3. & Aplikasi ms Excel & Sangat Bagus & $\begin{array}{l}\text { pemberian no. Ref pada laporan. } \\
\text { Peserta mengetahui cara menjalankan } \\
\text { aplikasi ms excel dalam pembuatan }\end{array}$ \\
\hline 4. & $\begin{array}{l}\text { Pembuatan Laporan } \\
\text { Keuangan pada ms } \\
\text { Excel }\end{array}$ & Sangat Bagus & $\begin{array}{l}\text { laporan keuangan. } \\
\text { Peserta mengetahui dan memahami } \\
\text { bagaimana cara membuat laporan } \\
\text { keuangan dengan menggunakan } \\
\text { aplikasi ms excel secara cepat dan } \\
\text { praktis }\end{array}$ \\
\hline
\end{tabular}

\section{Kesimpulan}

Dari kegiatan pengabdian yang telah dilakukan, maka diperoleh hasil bahwa peserta sangat berminat dengan pelatihan ini. Penambahan pengetahuan bagi peserta tentang pengelolaan keuangan koperasi yang baik dan benar, serta bagaimana membuat laporan keuangan secara cepat dengan menerapkan aplikasi ms. excel. Permasalahan utama yang dihadapi oleh peserta adalah mereka tidak tahu bagaimana cara membuat link antar bagian untuk masing-masing transakasi keuangan pada excel sehingga terintegrasi dalam bentuk akhir berupa laporan keuangan dan bagaimana cara membuat anggaran keuangan koperasi untuk tahun mendatang. Peserta merasakan manfaat dari pelatihan yang diikutinya, sehingga mereka tahu dan paham bagaimana cara untuk membuat laporan keungan koperasi yang tepat waktu dengan menerapkan aplikasi ms. Excel dan bagaimana membuat anggaran keuangan untuk koperasi. Berdasarkan tugas yang diberikan kepada peserta, mereka telah dapat membuat laporan keuangan dengan aplikasi ms. excel.

\section{Ucapan Terimakasih}

Ucapan terima kasih kepada Lembaga Penelitian dan Pengabdian Kepada Masyarakat (LPPM) Universitas Negeri Padang yang telah mendanai kegiatan pengabdian ini dan seluruh pihak yang telah mendukung pelaksanaan kegiataan ini sehingga dapat terlaksana dengan baik. 
Vol. 1. No. 4 Desember 2021

\section{Referensi}

Arifin Sitio \& Halomoan Tamba. 2001. Koperasi: Teori dan Praktik. Jakarta. Penerbit Erlangga

Eugene F.Brigham and Joel F.Houston. 2006. Fundamental of FinancialManagement (Dasar-Dasar Manajemen Keuangan). Jakarta. SalembaEmpat

Elvyin G. Masassy. 2004. Cara Cerdas mengelola Investasi Keluarga. jakarta. Gramedia

Hendar. 2010. Manajemen Perusahaan Koperasi. Jakarta. Penerbit Erlangga

Husnan, Suad. 2004. Manajemen Keuangan Teori dan Penerapan, edisi 3. Yogyakarta. BPFE.

Horne James C. Van \&Wachowicz John M. Jr.2005. Prinsip-Prinsip Manajemen Keuangan. Jakarta. Penerbit: Salemba Empat

John J. Wild, KR. Subramanyam, Robert F Healsey. 2005. Financial statement Analysis: Analisis Laporan Keuangan. Buku 1 dan 2. Jakarta. Salemba Empat.

Keown Arthur J \& Scott David F. 2008. Dasar-Dasar Manajemen Keuangan. Jakarta. Salemba Empat 